\title{
EFFECT OF EARLY FEEDING ON CELLULARITY OF RAT ADIPOSE TISSUE
}

\author{
Muneo TsUJIKAWA and Shuichi KIMURA ${ }^{1}$ \\ Laboratory of Nutrition, Faculty of Agriculture, \\ Tohoku University, Sendai 980, Japan
}

(Received May 12, 1980)

\begin{abstract}
Summary Effect of food intake at various ages (fetal, suckling and weaning periods) on adipose tissue cellularity was studied.

1) Rats were given a restricted diet on weaning and later allowed free access to diet. Fat pads of these animals recovered normal weight on refeeding and no differences in cell number or cell size were observed.

2) Food intake was varied by changing the litter size during the suckling period and, after weaning, animals were given free access to diet. Fat pads of rats raised in small litters were heavier than those of rats raised in large litters. The differences in adipose tissue weight were accounted for by differences in cell size and cell number.

3) Maternal rats were given a restricted diet during pregnancy. The pups were irregular in their weight. Pups of the restricted group which were smaller than pups of the control group at birth were chosen and raised normally. Fat pads of these animals were lighter than those of control animals and could be explained in terms of differences in cell size.

From these findings, it was suggested that cellular effects of early feeding depended on the phase of growth in the rat.

Keywords adipose tissue, cellularity, growth, food intake
\end{abstract}

It has been shown that animal growth and organ development are influenced by nutritional factors during development (1-3), but few studies concerned with the effect of early nutrition on the growth of adipose tissue have been reported (4). The weight of adipose tissue is dependent upon the number and size of fat cells. Fat cells are said to be nonmitotic and are expected to be of fixed number in the adult rat (5). Studies using DNA as a measure of cell number are numerous, but it has been suggested that the DNA content of adipose tissue does not indicate the number of fat cells (6). In the present study, adipose tissue cellularity was measured microscopically to obtain information related to the etiology of obesity and normal development of adipose tissue. And the effect of food intake at various ages during development on the growth of adipose tissue was determined.

1 辻川宗男, 木村修一 


\section{MATERIALS AND METHODS}

Feeding schedule on weaning. All animals used were male Wistar albino rats. Diet composition was starch $69 \%$, casein $20 \%$, soybean oil $5 \%$, salt mixture $(7) 4 \%$, water-soluble vitamin mixture (7) $1 \%$, and fat-soluble vitamin mixture $1 \%$. One gram of fat-soluble vitamin mixture contains vitamin A 1,000 I.U., vitamin E $10 \mathrm{mg}$, vitamin D 200 I.U., $p$-amino benzoic acid $10 \mathrm{mg}$ and choline chloride $150 \mathrm{mg}$. Animals were weaned at the age of 3 weeks. Restricted rats thereafter received daily amounts equal to $50 \%$ of the intake of control rats for 3 weeks and then had free access to food. Control rats were fed normally throughout the experimental period.

Feeding schedule on suckling. At birth, some rats were raised in litters of four pups and other, litters of twenty pups. At the age of 3 weeks, all animals were fed in the usual way for the remaining experimental period.

Feeding schedule during fetal growth. Mature female rats were mated. Pregnant females were fed daily amounts equal to $40 \%$ of the intake of the unrestricted females. After delivery, pups were bred in the usual way. All animals were sacrificed at the ages of 9 or 12 weeks.

Determination of adipose cell number and size. Animals were sacrificed by ether anesthesia and epididymal fat pad and inguinal subcutaneous fat pad were removed immediately. Fat pads were prepared by the method of Hirsch (8). About $200 \mathrm{mg}$ fat pads were incubated at $37^{\circ} \mathrm{C}$ in a plastic vial. The vial included $3 \mathrm{ml}$ Krebs-Ringer bicarbonate buffer ( $\mathrm{pH} 7.4$ ) containing per $\mathrm{ml}: 0.54 \mathrm{mg}$ glucose, $40 \mathrm{mg}$ bovine serum albumin fraction V (Armour Pharmaceutical Co.) and $1.33 \mathrm{mg}$ collagenase type 1 (Sigma Chemical Co.). After one hour, adipocytes were washed gently with cold buffer and then left at $4^{\circ} \mathrm{C}$. After one hour, a $10 \mathrm{ml}$ aqueous solution containing $0.25 \%$ trichloroacetic acid and $6.25 \%$ glutaraldehyde fixative was added to the chilled cells. Fat cells were again left at $4^{\circ} \mathrm{C}$ for one hour. Plastic Pasteur pipettes were used to transfer drops of cell suspension onto plastic slides. Drops were placed with a slight convexity and fat cells were dispersed as a single layer. Diameters of 200-300 cells per sample were measured using a calibrated ocular micrometer within one hour. The lipid was extracted according to the method of Folch (9) and assayed by the method of Renkonen (10).

\section{RESULTS}

\section{Effect of dietary restriction on weaning}

The body weight for restricted rats was maintained at a low level during the restricted period. At the end of the restricted period, the body weight for the restricted group was less than half of that for the control group. However, when restricted animals were fed ad libitum, they immediately showed a marked increment in the rate of weight gain and were inclined to approach the level of growth of the control rats (Fig. 1). The differences in weight of epididymal fat 


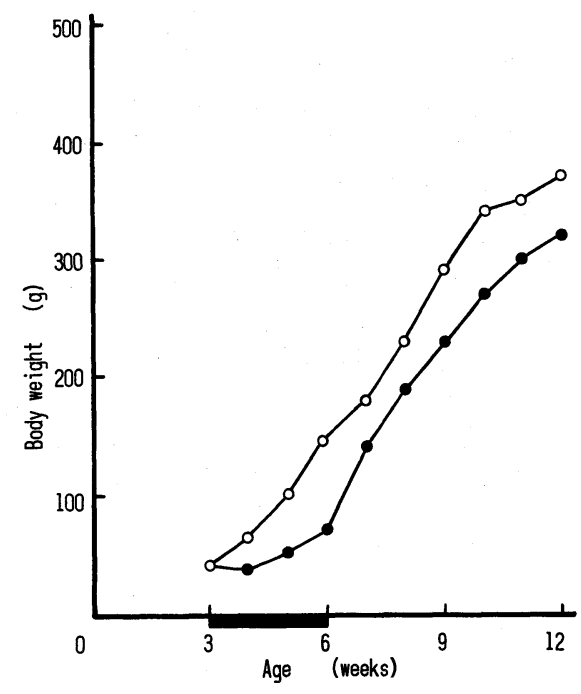

Fig. 1. Effect of dietary restriction on weaning on body weight of rats. $\bigcirc$, control; restricted.

Table 1. Effect of dietary restriction on weaning on epididymal adipose tissue weight and cellularity.

\begin{tabular}{cllccc}
\hline Age & \multicolumn{1}{c}{ Group } & Pad weight & Cell volume & Cell number \\
\hline (weeks) & & & $(\mathrm{g})$ & $(\mu \mathrm{g}$ lipid/cell) & $\left(\times 10^{6}\right)$ \\
9 & Control & $(5)$ & $1.35 \pm 0.21$ & $0.2134 \pm 0.0232$ & $5.08 \pm 0.51$ \\
& Restricted & $(6)$ & $1.18 \pm 0.06$ & $0.1924 \pm 0.0071$ & $4.83 \pm 0.16$ \\
& & & & & \\
12 & Control & $(6)$ & $2.68 \pm 0.32$ & $0.3091 \pm 0.0336$ & $6.97 \pm 0.41$ \\
& Restricted & $(7)$ & $2.26 \pm 0.38$ & $0.2937 \pm 0.0355$ & $6.05 \pm 0.40$ \\
\hline
\end{tabular}

Values represent means \pm SEM. The number of animals is indicated in parenthesis.

pads, adipose cell number and cell size between control rats and restricted rats were not significant at the age of either 9 or 12 weeks (Table 1). The differences in weight of subcutaneous fat pads, adipose cell number and cell size were also not significant (Table 2).

\section{Effect of litter size on suckling}

At the age of 3 weeks, large differences in the body weights were observed. The average body weight for a litter size of four at this time was $60 \mathrm{~g}$ compared to $27 \mathrm{~g}$ for a litter size of twenty. The difference in weight continued until the termination of the study. The difference in body weight was about $70 \mathrm{~g}$ at the age of 9 weeks and about $100 \mathrm{~g}$ at the age of 12 weeks (Fig. 2). Epididymal pad weights of 
Table 2. Effect of dietary restriction on weaning on subcutaneous adipose tissue weight and cellularity.

\begin{tabular}{cllccc}
\hline Age & \multicolumn{2}{c}{ Group } & Pad weight & Cell volume & Cell number \\
\hline (weeks) & & & $(\mathrm{g})$ & $(\mu \mathrm{g}$ lipid/cell) & $\left(\times 10^{6}\right)$ \\
9 & Control & $(5)$ & $1.56 \pm 0.24$ & $0.2145 \pm 0.0207$ & $4.70 \pm 0.48$ \\
& Restricted & $(6)$ & $1.46 \pm 0.08$ & $0.2395 \pm 0.0160$ & $4.30 \pm 0.27$ \\
& & & & & \\
12 & Control & $(6)$ & $2.88 \pm 0.33$ & $0.3011 \pm 0.0304$ & $6.55 \pm 0.59$ \\
& Restricted & $(7)$ & $2.27 \pm 0.23$ & $0.2864 \pm 0.0357$ & $5.40 \pm 0.28$ \\
\hline
\end{tabular}

Values represent means \pm SEM. The number of animals is indicated in parenthesis.

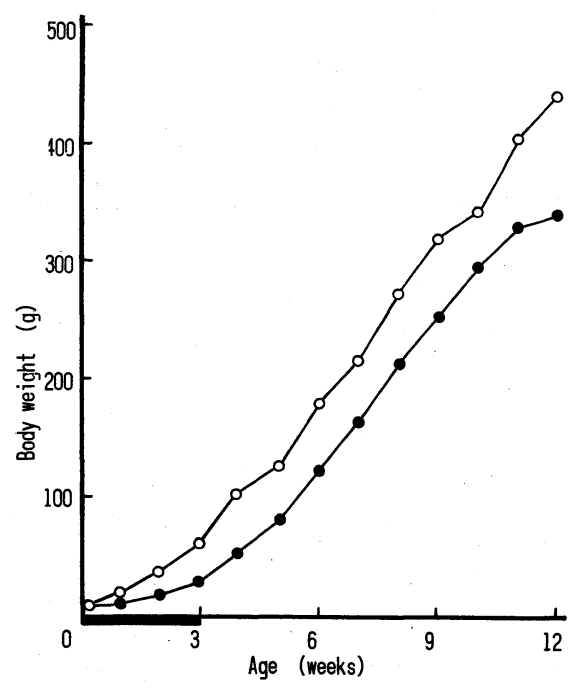

Fig. 2. Effect of litter size on body weight of rats. $\bigcirc, 4$ siblings; $\bullet, 20$ siblings.

animals from small litters were about two-fold heavier than those of rats from large litters at the age of 9 weeks and about 1.8 -fold at the age of 12 weeks. These differences were due to differences in cell number and cell size (Table 3). Subcutaneous pad weights of small litters were about twice those of large litters at 9 weeks of age and about 1.6-fold at 12 weeks of age. Significant differences in cell number and cell size were observed between both groups (Table 4).

Effect of maternal dietary restriction during gestation

Seventeen female rats were given restricted diet during gestation. The effects of malnutrition on delivery were various. Four female rats aborted or gave birth to stillborn pups. Although three were delivered of pups, the mothers were not capable of lactating. Newborn rats of five restricted females had lower body 
Table 3. Effect of litter size on epididymal adipose tissue weight and cellularity.

\begin{tabular}{ccccc}
\hline Age & Litter size & Pad weight & Cell volume & Cell number \\
\hline (weeks) & & $(\mathrm{g})$ & $(\mu \mathrm{g}$ lipid $/$ cell $)$ & $\left(\times 10^{6}\right)$ \\
9 & $4(6)$ & $2.21 \pm 0.20$ & $0.2459 \pm 0.0094$ & $7.53 \pm 0.54$ \\
& $20(8)$ & $1.10 \pm 0.07^{*}$ & $0.1626 \pm 0.0048^{*}$ & $5.47 \pm 0.52^{*}$ \\
& & & & \\
12 & $4(8)$ & $3.47 \pm 0.21$ & $0.3129 \pm 0.0109$ & $9.46 \pm 0.37$ \\
& $20(7)$ & $1.93 \pm 0.09^{*}$ & $0.2553 \pm 0.0097^{*}$ & $6.52 \pm 0.21^{*}$ \\
\hline
\end{tabular}

Values represent means \pm SEM. Significantly different from litter size $4 *(p<0.01)$. The number of animals is indicated in parenthesis.

Table 4. Effect of litter size on subcutaneous adipose tissue weight and cellularity.

\begin{tabular}{ccccc}
\hline Age & Litter size & Pad weight & Cell volume & Cell number \\
\hline (weeks) & & $(\mathrm{g})$ & $(\mu \mathrm{g}$ lipid $/$ cell $)$ & $\left(\times 10^{6}\right)$ \\
9 & $4(6)$ & $2.45 \pm 0.16$ & $0.2883 \pm 0.0124$ & $6.31 \pm 0.35$ \\
& $20(8)$ & $1.22 \pm 0.12^{*}$ & $0.1993 \pm 0.0070^{*}$ & $4.24 \pm 0.35^{*}$ \\
& & & & \\
12 & $4(8)$ & $3.22 \pm 0.16$ & $0.3719 \pm 0.0224$ & $6.46 \pm 0.33$ \\
& $20(7)$ & $2.01 \pm 0.13^{*}$ & $0.2914 \pm 0.0108^{*}$ & $5.12 \pm 0.45^{* *}$ \\
\hline
\end{tabular}

Values represent means \pm SEM. Significantly different from litter size $4 *(p<0.01)$, $* *(p<0.05)$. The number of animals is indicated in parenthesis.

weights than those of unrestricted females, but it was also observed that the body weights of newborn rats of five restricted females were almost equal to those of unrestricted females. Those pups with lower body weights were considered to be influenced by maternal malnutrition, so those were chosen for experiment to determine the recovery of body weight and adipose tissue cellularity. At the age of 3 weeks, the mean weight for restricted animals was about $36 \mathrm{~g}$ compared to about $40 \mathrm{~g}$ for unrestricted animals. The differences in body weight between both groups widened after weaning despite the fact that both groups had free access to food. The differences were $40 \mathrm{~g}$ at the age of 9 weeks and $60 \mathrm{~g}$ at the age of 12 weeks (Fig. 3). Significant differences in epididymal pad weights for each group of animals were observed at the ages of 9 and 12 weeks. The differences between each deposit was accompanied by differences in cell size, but no significant differences in cell number were found (Table 5). Significant differences were also observed in subcutaneous pad weights between both groups at the ages of 9 and 12 weeks. These differences were due to differences in cell size, but no significant differences in cell number between both groups were seen (Table 6). 


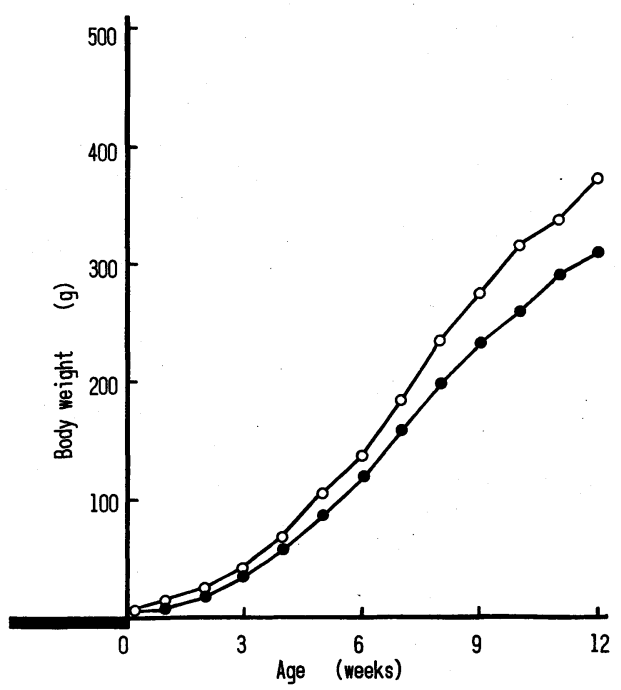

Fig. 3. Effect of maternal dietary restriction during gestation on body weight of pups. O, control; $\bullet$, restricted.

Table 5. Effect of maternal dietary restriction during gestation on epididymal adipose tissue weight and cellularity of pups.

\begin{tabular}{cllccc}
\hline Age & \multicolumn{2}{c}{ Group } & Pad weight & Cell volume & Cell number \\
\hline (weeks) & & & $(\mathrm{g})$ & $(\mu \mathrm{g}$ lipid/cell $)$ & $\left(\times 10^{6}\right)$ \\
9 & Control & $(8)$ & $1.74 \pm 0.06$ & $0.2159 \pm 0.0093$ & $6.64 \pm 0.27$ \\
& Restricted & $(7)$ & $1.39 \pm 0.05^{*}$ & $0.1751 \pm 0.0109^{* *}$ & $6.59 \pm 0.31$ \\
& & & & & \\
12 & Control & $(7)$ & $3.52 \pm 0.20$ & $0.3814 \pm 0.0252$ & $7.65 \pm 0.22$ \\
& Restricted & $(7)$ & $2.42 \pm 0.16^{*}$ & $0.2643 \pm 0.0156^{* *}$ & $7.81 \pm 0.42$ \\
\hline
\end{tabular}

Values represent means \pm SEM. Significantly different from control group $*(p<0.01)$, ** $(p<0.02)$. The number of animals is indicated in parenthesis.

\section{DISCUSSION}

Normal growth in the various organs of the rat can be defined as being of three phases: hyperplasia, hyperplasia plus hypertrophy, and hypertrophy (11). It is thought that the time at which a shift from one phase to another occurs differs according to organ. Winick et al. reported that in animals malnourished on weaning, brain and lung had normal DNA content while liver, kidney and muscle had reduced DNA content (2).

In the present experiment, when animals were malnourished on weaning, recovery of fat cell size and cell number occurred on refeeding. However, persistent 
Table 6. Effect of maternal dietary restriction during gestation on subcutaneous adipose tissue weight and cellularity of pups.

\begin{tabular}{cllccc}
\hline Age & \multicolumn{2}{c}{ Group } & Pad weight & \multicolumn{1}{c}{ Cell volume } & \multicolumn{1}{c}{ Cell number } \\
\hline (weeks) & & & \multicolumn{1}{c}{$(\mathrm{g})$} & $(\mu \mathrm{g}$ lipid $/$ cell $)$ & $\left(\times 10^{6}\right)$ \\
9 & Control & $(8)$ & $1.98 \pm 0.15$ & $0.2464 \pm 0.0138$ & $5.68 \pm 0.36$ \\
& Restricted & $(7)$ & $1.49 \pm 0.08^{* *}$ & $0.2050 \pm 0.0069^{* * *}$ & $5.10 \pm 0.30$ \\
& & & & & \\
12 & Control & $(7)$ & $3.07 \pm 0.15$ & $0.3652 \pm 0.0197$ & $6.20 \pm 0.32$ \\
& Restricted & $(7)$ & $2.00 \pm 0.08^{*}$ & $0.2548 \pm 0.0102^{*}$ & $5.68 \pm 0.15$ \\
\hline
\end{tabular}

Values represent means \pm SEM. Significantly different from control group $*(p<0.01)$, ${ }^{* *}(p<0.02),{ }^{* * *}(p<0.05)$. The number of animals is indicated in parenthesis.

changes in adipose tissue cellularity were brought about by altering litter size during the suckling period, despite the fact that animals had free access to food after weaning. It was expected that the suckling rats could not regulate the appetite thoroughly. This result is similar to that of Hirsch who used a cell counting method (4). The relation between the fat pads of animals raised in middle-sized litters and those in large-sized litters is not distinct and should be further studied. When maternal rats were given restricted diets during pregnancy, the fat pads were reduced in weight without effect on cell number. The striking difference in body weight between both groups was not observed at the age of 3 weeks. Even if animals are given a restricted diet before birth, provided they are bred normally during the suckling period, it may be expected that fat cells will proliferate normally. It would be possible that adipocytes in the rat proliferate at the highest rate during the suckling period, after which the transition from cell division to cell enlargement gradually occurs. The mechanism whereby adipocyte proliferation is regulated are, however, not known. It has been reported that anterior pituitary hormones may play a role in DNA synthesis in the brain, heart, liver and kidney (12). Similarly, anterior pituitary hormones may be involved in the division of fat cells. Relevant in this report is the study of Salans et al. who reported that insulin did not influence the proliferation of fat cells during development (13).

It has been reported that early dietary manipulation exerts a negative influence on brain development (14). Therefore, the decrease in adipose tissue weights by dietary manipulation might have resulted from changes in food intake after weaning. The quantity and quality of nutrition necessary to produce changes in adipose tissue cellularity should be further studied.

\section{REFERENCES}

1) McCance, R. A., and Widdowson, E. M. (1962): Nutrition and growth. Proc. Roy. Soc. Lond., 156, 326-337.

Vol. 26, No. 5, 1980 
2) Winick, M., and Noble, A. (1966): Cellular response in rats during malnutrition at various ages. J. Nutr., 89, 300-306.

3) Chow, B. F., and Lee, C. J. (1964): Effect of dietary restriction of pregnant rats on body weight gain of the offspring. J. Nutr., 82, 10-18.

4) Knittle, J. L., and Hirsch, J. (1968): Effect of early nutrition on the development of rat epididymal fat pads. J. Clin. Invest., 47, 2091-2098.

5) Goss, R. J. (1966): Hypertrophy versus hyperplasia. Science, 153, 1615-1620.

6) Rodbell, M. (1964): Localization of lipoprotein lipase in fat cells of rat adipose tissue. J. Biol. Chem., 239, 753-755.

7) Harper, A. (1959): Amino acid balance and imbalance. J. Nutr., 68, 405-418.

8) Hirsch, J., and Gallian, E. (1968): Methods for the determination of adipose cell size in man and animals. J. Lipid Res., 9, 110-119.

9) Folch, J., Lees, M., and Sloane-Stanley, G. H. (1957): A simple method for the isolation and purification of total lipids from animal tissues. J. Biol. Chem., 226, 497-509.

10) Renkonen, O. (1961): A note on spectrophotometric determination of acyl ester groups in lipid. Biochim. Biophys. Acta, 54, 361-362.

11) Winick, M. (1968): Nutrition and cell growth. Nutr. Rev., 26, 195-197.

12) Winick, M.; and Grant, P. (1968): Cellular growth in the organs of the hypopituitary dwarf mouse. Endocrinology, 83, 544-547.

13) Salans, L. B., Zarnowski, M. J., and Segal, R. (1972): Effect of insulin upon the cellular character of rat adipose tissue. J. Lipid Res., 13, 616-623.

14) Winick, M. (1970): Nutrition and nerve cell growth. Fed. Proc., 29, 1510-1515. 